\title{
Иностранные языки в России XVIII в.
}

\section{Foreign Languages in Eighteenth-Century Russia}

\author{
Татьяна Костина \\ Санкт-Петербургский институт истории Российской Академии наук \\ Tat'iana Kostina \\ St. Petersburg Institute of History of the Russian Academy of Sciences \\ tatianav.kostina@gmail.com
}

\begin{abstract}
:
This article presents a summary of the reports and transcripts of the discussion held on October 24, 2020, at a panel on the functioning of foreign languages in $18^{\text {th }}$-century Russia, which took place during the international conference "Müller Readings-2020." The attendees discussed different approaches to the subject using various historical examples, such as the language of the manuscripts presented to Peter the Great and Catherine I; the languages of Russian-Turkish diplomacy in the reign of Peter the Great; the problems of the horizon of the translator and the genre conditionality of the use of languages; their use in the initial period of the existence of the St. Petersburg Academy of Sciences; and the problems of publishing foreign language sources. Several reports were devoted to the history of teaching foreign languages among various social strata, as well as to the methods of teaching languages in the 18th century.
\end{abstract}

Keywords:

“Müller Readings-2020" Conference; foreign languages in Russia; eighteenth century

21-24 октября 2020 г. в Санкт-Петербурге прошла международная научная конференция "Миллеровские чтения - 2020." В последний день конференции, дистанционно, на платформе ZOOM, состоялось научное заседание секции, посвященной бытованию иностранных языков в Российской империи XVIII в. Это центральный вопрос для изучения культуры эпохи Просвещения, и заседание, посвященное ему, вызвало определенный резонанс в научном сообществе. Мы предлагаем вниманию читателей развернутые резюме докладов и дискуссии.

В первой части секции, состоящей из пяти докладов, были продемонстрированы разные подходы к проблеме функционирования языков.

Открылось заседание выступлением И. А. Вознесенской (Библиотека РАН, Санкт-Петербург), которая в последние годы комплексно занимается подносными книгами в собрании Рукописного отдела Библиотеки Российской

\footnotetext{
${ }^{1}$ Работа выполнена при финансовой поддержке Российского фонда гуманитарных исследований [далее РФФИ] и Фонда “Дом наук о человеке” Франции [далее ФДНЧ], в рамках научного проекта № 20-513-22001.

2 Полное название конференции, организованной Санкт-Петербургским филиалом Архива РАН, -“Миллеровские чтения - 2020: Преемственность и традиции в сохранении и изучении документального академического наследия." Ранее конференции “Миллеровские чтения” состоялись в 2013 и 2018 г.
} 
Академии наук. ${ }^{3}$ В докладе “Языки подносных экземпляров из библиотеки Петра I"4 она рассказала о библиотеке первого императора, в составе которой сохранилось около 40 рукописных книг, представляющих собой подносные экземпляры. В данном докладе она проинформировала о 25 рукописных книгах библиотеки Петра I на иностранных языках, составляющих 10\% от всех рукописей библиотеки, и сосредоточилась на описании шести из них, представляющих собой подносные экземпляры. Четыре из них подносились Петру I, ${ }^{5}$ a две Екатерине I. ${ }^{6}$ В докладе были прослежены обстоятельства создания, поднесения и, в ряде случаев, перевода на русский язык и издания этих сочинений.

Подводя итоги, И. А. Вознесенская заметила, что рукописи подносились на языках понятных императору и императрице, либо содержали перевод (как в случае с подношением Кантемиров), но, фактически, они потерялись в недрах библиотеки, а поднесенные тексты не получили широкого распространения ни в рукописном, ни в печатном виде.

\section{Вопросы и дискуссия:}

А. М. Новикова (Национальный исследовательский университет “Высшая школа экономики” в Санкт-Петербурге): “Вы упоминали, что в Библиотеке Петра I были французские рукописи. О чем они были и каким годом датированы?”

И. А. Вознесенская: "Рукописи на французском языке (их, кажется, шесть) были получены Петром I в подарок во время его поездки во Францию в 1717 г. Это знаменитые альбомы с планами Версаля и Марли, Устав ордена Св. Духа, грамматика французского языка и др. Несмотря на то, что это подарки, они не относятся к подносным экземплярам, потому что они не были сделаны

\footnotetext{
${ }^{3}$ И. А. Вознесенская, “Подносной экземпляр трактата 'О народном просвещении и правосудии' Михайлы Аврамова из собрания БАН,” Петербургская библиотечная школа № 1 (2017): 37-41. (I. А. Voznesenskaia, "Podnosnoi ekzempliar traktata 'O narodnom prosveschchenii i pravosudii' Mikhaily Avramova iz sobraniia BAN," Peterburgskaia bibliotechnaia shkola, 1 (2017): 37-41); И. А. Вознесенская, “Подносные панегирики братьев Лихудов Петру I из собрания БАН," Ученые записки Новгородского государственного университета имени Ярослава Мудрого № 5 (30) (2020), 4ю (I. А. Voznesenskaia, "Podnosnye panegiriki brat'ev Likhudov Petru I iz sobraniia BAN," Uchenye zapiski Novgorodskogo gosudarstvennogo universiteta imeni Iaroslava Mudrogo, 5:30 (2020), 4).

${ }^{4}$ Доклад подготовлен при финансовой поддержке РФФИ в рамках научного проекта № 20-09-42003 Петровская эпоха.

${ }^{5}$ БАН, П І Б, № 154: Adriann Schoonebeck, Korte maniere om de Ets-Konst velkomen te leeren, 1698. Ha голл. яз. (BAN, P I В, № 154: Adriann Schoonebeck, Korte maniere om de Ets-Konst velkomen te leeren, 1698. Na goll. iaz.); БАН, П І Б. № 9: Dorotheo Alimari, Bellona Recens Armis Exercita, 1699. На лат. яз. (BAN, P I B, № 9: Dorotheo Alimari, Bellona Recens Armis Exercita, 1699. Na lat. Iaz.); БАН. П I Б. № 42: Daniel Waeywel, Tractaet... der Quadratura Circuli, 1717. На голл. яз. (BAN, P I В, № 42: Daniel Waeywel, Tractaet... der Quadratura Circuli, 1717. Na goll. iaz.); БАН. П I Б. № 150: Сербан Кантемир, Панегирик; Дмитрий Кантемир, Рассуждение физическое о монархиях. 1714. На лат., греч. и рус. яз. (BAN, P I B, № 15o. Serban Cantemir, Panegirik; Dmitrii Kantemir, Rassuzhdenie fizicheskoe o monarkhiiakh. 1714. Na lat., grech. i rus. iaz.).

${ }^{6}$ БАН, П І Б № 107: Иван Максимович, Латинско-русский словарь. 1724. На лат. и рус. яз. (BAN, Р I В, № 107: Ivan Maksimovich, Latinsko-russkii slovar', 1724. Na lat. i rus. iaz.); БАН, П І Б. № 151: Thomas Consett, Concio-congratulatoria de Imperatrice Catharina, nuper Moscvae coronate, 1724. На лат. яз. (BAN, P I B, № 151: Thomas Consett, Concio-congratulatoria de Imperatrice Catharina, nuper Moscvae coronate, 1724. Na lat. iaz.).
} 
специально для Петра. Например, Устав ордена Св. Духа был скорее всего выполнен для Людовика XIV.”

Т. В. Костина (СПбИИ РАН): “Есть ли на подносных экземплярах читательские пометы?"

И. А. Вознесенская: “Читательских помет нет. На рукописи Сербана и Дмитрия Кантемиров очень много помет, но они редакторские. Возможно, их появление связано с изданием этой рукописи. Остальные рукописи не имеют помет.”

$$
* * *
$$

Доклад Т. А. Базаровой (СПбИИ РАН) “Дипломатический язык русских послов в Стамбуле в Петровскую эпоху” был посвящен языкам, на которых велись переговоры и составлялись международные договоры и соглашения. ${ }^{7}$

В Петровскую эпоху языком общения между европейскими дипломатами и Высокой Портой был не турецкий, а итальянский, активно использовался и греческий. Постоянные представители западноевропейских держав в Стамбуле, как правило, турецким не владели. Хотя были и исключения. Например, хорошо знал разговорный турецкий голландский посол Якоб Кольер, что позволяло ему общаться с османскими министрами без переводчиков. Петр I при выборе будущего главы дипломатической миссии обращал внимание на языковую подготовку кандидата: итальянским владели Д. М. Голицын, П. А. Толстой, И. И. Неплюев, латынью А. И. Дашков. По-видимому, уже в Стамбуле разговорным итальянским на основе латыни овладел вице-канцлер П. П. Шафиров. При неофициальных контактах с представителями Порты, западноевропейскими дипломатами, агентами и информаторами использовали и другие языки.

\footnotetext{
7 Доклад подготовлен при поддержке РФФИ, грант № 18-о9-о0721. Ранее исследование было начато в других работах. См.: Т. А. Базарова, "Материалы походной канцелярии вице-канцлера П. П. Шафирова о деятельности русских дипломатов в Османской империи в 1713-1714 гг.," Вспомогательные исторические дисциплины, Т. XXXI (2010): 348-355. (Т. A. Bazarova, "Materialy pokhodnoi kantseliarii vitse-kantslera P. P. Shafirova o deiatel'nosti russkikh diplomatov v Osmanskoi imperii v 1713-1714 gg.," Vspomogatel'nye istoricheskie distsipliny 31 (2010): 348-355); Т. А. Базарова, "Статейные списки русских послов при Высокой Порте 1711-1714 гг.: история создания и перспективы изучения," Вспомогательные исторические дисциплины, Т. XXXIV (2014): 78-93. (Т. А. Bazarova, "Stateinye spiski russkikh poslov pri Vysokoi Porte 1711-1714 gg.: istoriia sozdaniia i perspektivy izucheniia," Vspomogatel'nye istoricheskie distsipliny, 34 (2014): 78-93); Т. А. Базарова, “Переводчики русских послов в Стамбуле в начале XVIII в.," в Переводчики и переводы в России конца XVI-начала XVIII столетий: Материалы Международной научной конференции. (Москва: Институт российской истории $\mathrm{PAH}, 2019)$, 9-16. (Т. A. Bazarova, "Perevodchiki russkikh poslov v Stambule v nachale XVIII v.", in Perevodchiki i perevody v Rossii kontsa XVI-nachala XVIII stoletii: Materialy Mezhdunarodnoi nauchnoi konferentsii (Moscow: Institut rossiiskoi istorii RAN, 2019), 9-16; T. A. Барарова “Для лутчаго и состоятельнейшаго оного мира охранения...': пребывание русского посла П. А. Толстого при османском дворе,” Труды Государственного Эрмитажа. [T.] 101: Петровское время в лицах: материалы научной конференциии (Санкт-Петербург: Издательство Государственного Эрмитажа, 2019), 53-6o. (Т. A. Bazarova, "'Dlia lutchago i sostoiatel'neishago onogo mira okhraneniia...': prebyvanie russkogo posla P. A. Tolstogo pri osmanskom dvore," Trudy Gosudarstvennogo Ermitazha. [T.] 101: Petrovskoe vremia v litsakh: materialy nauchnoi konferentsi (St. Petersburg: Izdatel'stvo Gosudarstvennogo Ermitazha, 2019), 53-6o).
} 
С послами в Порту отправляли переводчиков и толмачей со знанием итальянского, латыни, а также греческого и молдавского языков. На основе неопубликованных документов удалось установить, что в начале XVIII в. сотрудники русской миссии в Стамбуле изучали турецкий язык. В определенной мере (мог вести беседу и читать) им овладел уже сын П. А. Толстого Иван, находившийся в османской столице в качестве дворянина посольства до 1706 г. Успешно изучил разговорный турецкий подьячий Иван Небогатый, находившийся при посольстве в 1705-1707 гг. и с 1712 г. Недостаток специалистов также отчасти компенсировался приемом на русскую службу иностранцев. В 17121713 гг. для обучения сотрудников посольства (подьячих и переводчиков) был нанят учитель турецкого языка, а в 1720-х гг. резидент Иван Неплюев создал школу обучения иностранным языкам.

\section{Вопросы и дискуссия:}

В. С. Ржеуцкий (Германский исторический институт в Москве): "У меня несколько уточняющих вопросов: 1. На каких источниках основан доклад? 2. Какой период Вы охватываете в своих исследованиях? 3. Появляется ли при взаимодействии с Портой в качестве дипломатического языка французский?”

Т. А. Базарова пояснила, что работает с письмами, реляциями русских послов, указами, рескриптами, статейными списками. Эти материалы сохранились в РГАДА, в АВПРИ [Архив внешней политики Российской Империи], также отдельные документы сохранились и в Архиве СПбИИ РАН. Интересует период с 1699 г. и до окончания Северной войны в 1721 г. Французский язык упоминается, но он не использовался в переговорах.

Д. В. Сень (Южный федеральный университет, Ростов-на-Дону): “В начале XVIII в. ачуевский мухафыз Хасан-паша просил И.А. Толстого, родного брата П. А. Толстого, писать ему на греческом и французском, мотивируя это тем, что читать письма на русском языке у него нет специалистов, но в крепости есть люди, владеющие упомянутыми языками. В связи с этим возникает вопрос: насколько для османской стороны была существенна проблема переводов, устных и письменных? При посредничестве кого османы решали проблему коммуникации с русскими?"

T. А. Базарова: “Франция была многолетним союзником Турции, что объясняет наличие у турок специалистов. Главные переводчики с османской стороны -- это греки-фанариоты из рода Маврокордато. Греческий использовался и для контактов русских с информаторами."

М. А. Петрова (Институт всеобщей истории Российской Академии наук, Москва): “Сохранились ли какие-то тексты Петра, в которых он пишет, что российским дипломатам необходимо знать язык страны пребывания?”

T. А. Базарова: "Мне такие тексты не встречались, но такое обсуждение могло происходить на уровне Посольского приказа." 
С. М. Шамин (Институт российской истории Российской Академии наук, Москва): "В Москве на протяжении XVII в. обычно держали 3-4 переводчика с турецкого языка. При этом Асанов умирает в 1701 г., перед этим Татаринов в 1694 г. Как Вы думаете, почему Петр I во время войны с Турцией не озаботился восстановлением численности переводчиков? И еще вопрос... Рамазан Тефкелев все-таки был переводчиком с турецкого или нет? Если был, то когда им стал?”

T. А. Базарова: "Материал не позволяет ответить на этот вопрос, некоторые действия Петра I приводят меня в тупик. Рамазан и его сын Муртаза иногда попадаются в документах, причем иногда их называют переводчиками, а иногда толмачами."

Дальнейшая дискуссия позволила прояснить судьбы отдельных переводчиков; увидеть, что специалисты со знанием турецкого языка распределялись между Посольским приказом, Азовом и Стамбулом.

$$
* * *
$$

Продолжила работу конференции Р. А. Евстифеева (Сорбонна, Париж) докладом "Горизонт эрудиции русского переводчика XVIII в.: случай С. С. Волчкова." ${ }^{\prime}$ Исследовательский интерес Евстифеевой в последние годы концентрируется на переводах произведений Бальтазара Грасиана, подготовлен соответствующий каталог, ${ }^{9}$ в процессе подготовки находится база данных по переводу лексики интеллектуальных качеств в трактатах Грасиана. Интерес к Волчкову обусловлен тем, что он перевел сочинение Грасиана "Придворный человек," однако для определения горизонта эрудиции использовались и другие его переводы. ${ }^{10}$

Вопрос о горизонте эрудиции переводчика стоит для исследователей очень остро, особенно, когда речь идет о первой половине XVIII в. Век Просвещения -это век активного политического и культурного трансфера, и значение переводчика как медиатора этого процесса велико. При этом практически не существовало институций, которые занимались подготовкой медиаторов или посредников, их появление происходило спонтанно. Отсюда вытекает проблема

\footnotetext{
${ }^{8}$ Доклад подготовлен в рамках проекта "VIR MAXIMUS: Tracking the Transfer of Moral-Political Ideas Through the Reception of B. Gracián's Texts (XVII-XXI cent.)," при финансовой поддержке от исследовательской и инновационной программы Европейского Союза "Horizon 2020," по гранту им. Марии Склодовской-Кюри № 839351.

${ }^{9}$ Riva Evstifeeva, "VIR MAXIMUS Catalogue," August 30, 2020, https://zenodo.org/record/4008175\#.XOrzyMgzY2w.

${ }^{10}$ P. А. Евстифеева, “Политический язык 'Придворного человека' - Political Language of 'The Courtly Man," в VIII Римские Кирилло-Мефодиевские чтения (5-1о февраля 2018). Материалы конференции, ред. Н. Запольская, М. Обижаева (Москва: Индрик, 2018), 33-36. (R. A. Evstifeeva, "Politicheskii iazyk 'Pridvornogo cheloveka' - Political Language of 'The Courtly Man'," in VIII Rimskie Kirillo-Mefodievskie chteniia (5-10 fevralia 2018). Materialy konferentsii, red. N. Zapol'skaia, M. Obizhaeva (Moscow: Indrik, 2018), 33-36); Р. А. Евстифеева, “Лексикология и переводоведение: лексика интеллектуальных качеств человека в Вояжировом лексиконе С. С. Волчкова (1755? - 1776)," L'analisi linguistica e letteraria XXVIII: 2 (2020): 73-84. (R. A. Evstifeeva, "Leksikologiia i perevodovedenie: leksika intellektual'nykh kachestv cheloveka v Voiazhirovom leksikone S. S. Volchkova (1755? - 1776)," L'analisi linguistica e letteraria 28:2 (2020): 73-84).
} 
адекватности эрудиции как инструментария в руках медиатора. Легитимация медиатора в должности переводчика происходила либо спонтанно, либо по поручению власти (как непосредственно, так и через институции: Коллегию иностранных дел, Коммерц-коллегию, Академию наук). Волчков поработал во всех трех в разное время. Кроме них в этот период зарождались новые инстанции легитимации. В карьере Волчкова их было две. Во-первых, профессиональное сообщество, которое работало как на легитимацию, так и на делегитимацию Волчкова как переводчика (поводом служило отсутствие формального образования). Во-вторых, для Волчкова имел большое значение рынок. Эту модель легитимации пытался создать сам Волчков, учитывая при выборе источника для перевода рыночный спрос на литературу определенных жанров, продвигая свои переводы в печать через Академию наук, когда он находился в должности директора Сенатской типографии и издавая сочинения за свой счет в типографии Сухопутного шляхетного кадетского корпуса.

Известно, что Волчков с 1722 г. был юнкером в Герольдмейстерской конторе, затем служил в Мануфактур-коллегии, в 1725 г. был послан в миссию России в Силезии. В 1728 г. делал переводы для Коллегии иностранных дел, в 1730-1735 г. был секретарем при послах в Берлине, изучал французский, после чего был принят в Академию президентом И. А. Корфом. В Академии Волчков занимался как делопроизводственными переводами с немецкого языка, так и, во внерабочее время, более “литературными,” переведя “Флоринову экономию,” “Придворного человека," “Мир душевный” и др. Однако переводы Волчкова нередко не доходили до печати, “застревая” на стадии рецензирования в Академии. Как из заявлений самого Волчкова, так и из его переводов видно, что он не владел латинским языком. Показателен перевод Волчкова из Плутарха (1750), в котором он называл Дионисия Денисом, Евстафия Евстатом, Есхиля Ешилем. Уже из этого видно, что переводчик вовсе не был знаком с античной культурой. В работе над “Придворным человеком” Волчков не различал текста и паратекста, делал частичный перевод примечаний, удалял или вливал с искажениями в общий текст цитаты античных авторов, время от времени ошибочно называя разных из них Тацитом, латинские цитаты систематически выбрасывал.

В выводах Р.А. Евстифеева отметила, что для изучения Нового времени проблема горизонта эрудиции переводчика очень важна, поскольку переводчик - центральная фигура в процессе культурного трансфера. Европейская литературная культура эпохи, кроме того, предусматривала знание древних языков и античной культуры. Поэтому Волчкову в работе было недостаточно только знания современных ему немецкого и французского языков. Это ставило его в уязвимую позицию в процессе легитимации как переводчика по разным, описанным выше, каналам.

\section{Вопросы и дискуссия:}

В. С. Ржеуцкий: "Можно ли сказать, что карьера Волчкова в Посольском приказе, на дипломатическом поприще -- это прежде всего следствие его знакомства с иностранными языками, или были еще какие-то обстоятельства? И еще... Вы очень хорошо показали переводческую манеру Волчкова. Можно ли сказать, что 
он каким-то образом выделяется на фоне переводчиков своего времени или в этом смысле он скорее явление эпохи?"

P. А. Евстифеева: "На первый вопрос ответ положительный, что очевидно не только из моего доклада, но и из доклада Т. Базаровой. Первые шаги на дипломатическом поприще, несомненно, были сделаны благодаря знанию немецкого языка. А второй вопрос скорее является перспективой для дальнейших исследований."

В. Берелович (Ecole des hautes études en sciences sociales, Женевский университет): “Меня заинтриговало наличие в источниках переводов Волчкова богословских книг и, в частности, среди ранних переводов книги пастора Дегура -- видного и ярого протестанта. Есть ли какие-то сведения по поводу заказа на перевод этой книги?"

P. А. Евстифеева: “Я предлагаю разделить вопрос на два аспекта: 1. наши сведения, вообще, о том, как происходил выбор/заказ книг на перевод; и 2. что происходит с присутствием богословской, мистической литературой в списке переводов Волчкова. Про некоторые книги Волчкова известно, что у них был заказчик (например, перевод Савариева лексикона был сделан по заказу Коммерц-коллегии), но, в основном, приходится об этом догадываться, а, возможно, заказа и не было. Представленная в докладе некоторая типология переводов сделана как раз для того, чтобы попытаться понять, что за ней может стоять, находя общие векторы. Вопрос с религией очень сложен. Я могу допустить, что Волчкова в какой-то момент пытались рассматривать как агента протестантизма в его пиетистском варианте."

С. М. Шамин: “Проблема, которую Вы обозначили, чуть в более раннее время особенно видна на уровне вообще всех переводчиков. Петр I едет через Митаву, ему иезуиты вручают Элогиум... Мы с Сергеем Викторовичем Алпатовым его опубликовали, сравнили с источником, стало очевидно, что переводчику не хватает эрудиции. ${ }^{11}$ И это касается не только конкретного случая. Очевидно, что пока у нас не появилось систематического образования, когда античность стали вбивать в головы, это оставалось серьезной проблемой.”

$$
* * *
$$

Следующий доклад сделала Дж. Ларокка (Университет г. Мачераты): “Полиглот при русском дворе. Якоб Штелин и иностранные языки (предварительные замечания).” Интеллектуальная биография Штелина (одописца, искусствоведа, воспитателя Петра III), его деятельность занимают центральное место в истории культуры и литературы XVIII в., но при этом еще малоизучены, несмотря на то, что недавно К. В. Малиновский опубликовал и

\footnotetext{
${ }^{11}$ С. В. Алпатов, С. М. Шамин, “Элогиум митавских иезуитов в документах Великого посольства 1697 г.," Древняя Русь. Вопросы медиевистики 4 (2014): 96-110 (S. V. Alpatov, S. M. Shamin, "Elogium mitavskikh iezuitov v dokumentakh Velikogo posol'stva 1697 g.," Drevniaia Rus'. Voprosy medievistiki 4 (2014): 96-110).
} 
переиздал многие из его работ. ${ }^{12}$ Помимо писем, которыми Штелин обменивался с разными дипломатами, писателями и математиками со всей Европы (на разных языках, но, в основном на французском и немецком, иногда на латинском), в архивах сохранились его оды на немецком (некоторые из них не были опубликованы), литературные очерки и стихи на французском языке. Материалы на итальянском языке создавались в двух жанрах. Это оперы и истории, в частности, так называемые исторические записки. В докладе Ларокка проанализировала черновики двух исторических записок, дошедшие до нас в неопубликованном виде. Она обратила внимание на то, что Штелин использовал один и тот же термин (“записки”) для обозначения одного и того же жанра: “Записки, служащие истории нашего времени” (1744) и “Исторические записки о коронации Ее Императорского Величества Елизаветы Первой. Сбор фактов и материалов" (не ранее 1770-х). Штелин в обоих случаях использовал для их создания итальянский язык, что вряд ли можно считать случайностью.

Повествование в “Записке...” (1744) балансирует между исторической реконструкцией и поэтическим лиризмом. Несмотря на незавершенность и конспективность “Исторических записок о коронации...” (не ранее 1770-х), видно, что цель Штелина заключалась в фиксации событий эпохи. Жанр, в котором Штелин писал эти произведения, можно сравнить с жанром “Memorie," хорошо знакомым итальянскому читателю XVIII в., который связывался в восприятии современников с произведениями научно-популярного характера. Однако самое раннее найденное произведение с таким названием вышло в Италии в 1742 г., из чего можно предположить, что вряд ли Штелин был знаком с ним и ориентировался на него. Сам термин был заимствован из французского языка, где использовался уже во второй половине XVII в., из чего можно сделать вывод, что источник этого жанра для Штелина, видимо, не итальянский, а французский. Остается открытым вопрос об употреблении для этого жанра Штелиным итальянского языка, имевшего в эти годы статус языка оперы, а также, как мы видели из доклада Т. А. Базаровой, языка дипломатии и межкультурного общения. Широта и многообразие использовавшихся Штелиным источников не позволяет с точностью определить причину выбора им итальянского языка для создания данных материалов. Тем не менее, представляется, что размышлять о жанрах необходимо, и контекст их создания говорит о том, что выбор языка был сделан не случайно.

\section{Вопросы и дискуссия:}

М. Шруба (Миланский университет): “Не было ли попытки узнать, для кого предназначались упомянутые труды Штелина? Почему немец писал в России на итальянском языке?"

Дж. Ларокка: “Это ключевой вопрос о том, кто был его аудиторией, но мы не можем прямо на него ответить. Скорее у Штелина была определенная иерархия,

\footnotetext{
${ }^{12}$ К. В. Малиновский, Материалы Якоба Штелина. В 3-х томах (Санкт-Петербург: КРИГА, 2015). (К. V. Malinovskii, Materialy Iakoba Shtelina. V 3-kh tomakh (St. Petersburg: KRIGA, 2015)); см. также: Giuseppina Larocca "New Perspectives on Jacob von Stählin: Towards an Intellectual Biography," Slavonica (June 2018): 1-11.
} 
он использовал разные языки для определенных жанров. Возможно, выбор языка определяло содержание записок. Он писал в этих текстах о масках, о балетах, и, возможно, поэтому испытывал итальянское влияние.”

$$
* * *
$$

Доклад “Немецкоязычные тексты Академии наук XVIII в.: проблемы публикации” М. Б. Лавринович (Национальный исследовательский университет "Высшая школа экономики," Москва) посвятила выработке принципов публикации текстов на немецком языке в сборнике документов "Учебные заведения Петербургской Академии наук: документы и материалы (1724-1747 гг.).”3 Работа с этими документами позволяет выявить основные черты языка, на котором говорили и писали сотрудники и чиновники Академии наук во второй четверти XVIII в.: это немецкий язык, отличающийся большим количеством галлицизмов и латинизмов.

В основу доклада положена работа над немецкими редакциями одного документа, хорошо известного в русском переводе, -- это “Проект об учреждении Академии наук” 22 января 1724 г. ${ }^{14}$ Удалось разыскать две немецкие редакции этого текста. В СПбФ АРАН сохранился вариант “А,” Подлинник перевода с пометами Петра I, неоднократно публиковавшийся, также сохранился в РГАДА. ${ }^{17}$ Установлено, что ни одна из найденных немецких редакций при этом не являлась источником перевода. Изучение водяных знаков на бумаге этих трех документов приводит к мысли о том, что документы действительно были созданы в 1720-е гг. Интересно, что обе немецких редакции переписаны одним почерком, принадлежащим писцу из канцелярии Л. Л. Блюментроста.

Создание Проекта пришлось на период унификации письма в интересах канцелярий (конец XVII -- начало XVIII вв.) и появления первых учебных пособий (прописей) по канцелярскому курсиву. ${ }^{18}$ В них рекомендовали строгое и четкое письмо, без размашистых петель и свободных росчерков; использование заостренных узких петель, прямых выносных. Почерк, которым написан “Проект," сохранил барочные элементы в заглавных буквах. Также в нем использованы сокращения (знак двоеточие) и вспомогательные значки для облегчения чтения: две точки над у -- ӱ и дуга над u -- й (не путать с ӥ); для переноса слов

\footnotetext{
${ }^{13}$ Доклад подготовлен при финансовой поддержке РФФИ, проект № 18-013-00595.

14 Такой заголовок является прямым переводом названия известного нам немецкого варианта проекта. Ранее русский перевод публиковался под заголовком “Проект положения об учреждении Академии наук и художеств,” данным ему исследователями при публикации.

${ }^{15}$ СПбФ АРАН, ф. 3: Комиссия Академии наук, оп. 1, д. 422: Acad. Cancell. Acten., 270-281 об. (SPbF ARAN, f. 3: Komissiia Akademii nauk, op. 1, d. 422: Acad. Cancell. Acten., 270-281 ob.).

${ }^{16}$ РГАДА, ф. 17: Наука, литература и искусство, оп. 1, д. 2: Бумаги графа А. И. Остермана, касающиеся Академии наук 1724-1725 годов, 5-19 об. (RGADA, f. 17: Nauka, literatura i iskusstvo, op. 1, d. 2: Bumagi grafa A. I. Ostermana, kasaiushchiesia Akademii nauk 1724-1725 godov, 5-19 ob.).

${ }_{17}^{17}$ РГАДА, ф. 1451: Именные указы Петра I Сенату и др. учреждениям, оп. 1, д. 18: Указы Петра I Сенату, 1724 г., 89-10o (RGADA, f. 1451: Imennye ukazy Petra I Senatu i dr. uchrezhdeniiam, op. 1, d. 18: Ukazy Petra I Senatu, 1724 g., 89-10o).

${ }^{18}$ M. Borgern, Vorschrifft und gründlicher Unterricht vor die Jugend in Anleitung zur Current-Cantzley und Fraktur Schrifft (Dresden, 1707); H. Curas, Calligraphia Regia: Königliche Schreib Feder dergleichen noch nie zum Vorschein kommen (Berlin, 1714).
} 
употреблены два прямых штриха. При этом слова с латинскими и французскими корнями (полностью или только их корни) выделены с помощью округлого письма, называемого антиква.

Очевидна необходимость издать выверенный немецкий текст, а также переиздать перевод, сверенный с подлинником и снабженный комментарием, в котором через обращение к немецкому тексту прояснить содержание самого “Проекта." Изучение двух вариантов немецкого текста с содержательной точки зрения показало, что вариант “В” более персонализирован, а также содержит больше галлицизмов, чем вариант “А.” Исходя из этого было принято решение публиковать вариант “В," а значимые отличия из редакции “А” отобразить в примечаниях. Для подготовки текста к изданию решено руководствоваться рекомендациями Рабочей группы по проблемам издания текстов раннего Нового времени (Arbeitskreis “Editionsprobleme der frühen Neuzeit"), созданной в 1976 г. ${ }^{19}$

Если при публикации текстов XVI-XVII вв. характерно стремление к максимальному сохранению внешних особенностей текста, а для публикации текстов XIX в. - стремление к стандартизации, то XVIII век находится в промежуточном положении. Поэтому решения по отношению к текстам, созданным в это время, каждый раз сугубо индивидуальны. В результате были согласованы следующие принципы для издания “Проекта" и его перевода: 1. сделать издаваемый текст доступным и полезным разным специалистам: педагогам, историкам, филологам, лингвистам; 2. не воспроизводить особенности, связанные с историей письма; 3. принимать во внимание все известные редакции; разночтения сообщать только в случае, если они фактически или лингвистически значимы; 4. пунктуацию нормализовать в соответствии с современными правилами; 5. корни и слова на латинском и французском языках отображать курсивом; 6. очевидные ошибки или фразы, требующие интерпретации, объяснять.

\section{Вопросы и дискуссия:}

P. А. Евстифеева: “Планируете ли вы публиковать изображения, сканы документа или только транскрипцию?”

T. В. Костина ответила, что изображения публиковать не планируется, а готовится именно комментированный текст, но, если будет получено разрешение СПбФ АРАН, то какой-то небольшой фото-фрагмент, возможно, будет приведен в качестве иллюстрации. Во всяком случае, это уже шаг вперед, потому что прежде ученые пользовались наскоро сделанным русским переводом, к тому же плохо изданным; последние издания “Проекта” сильно разнятся с оригиналом.

М. Б. Лавринович добавила, что “наша задача как раз опубликовать не образ документа и не транскрипцию, а обработанный документ.”

\footnotetext{
${ }^{19}$ R. Aulinger, G. Lutz, G. Müller, H. Scheible, D. Wuttke, "Empfehlungen zur Edition frühneuzeitlicher Texte," Jahrbuch der historischen Forschung in der Bundesrepublik Deutschland - Berichtsjahr 1980 (Stuttgart: Klett, 1981), 85-96.
} 
С. Менгель (Университет им. Мартина Лютера Галле-Виттенберг, директор Института славистики): “Вы сказали, что в комментариях будут учитываться только те разночтения, которые лингвистически или фактически значимы. Что понимается под лингвистически значимыми разночтениями?”

М. Б. Лавринович: “Мы указываем в примечаниях случаи, когда слово во втором списке написано иначе, но больших лингвистических проблем в этом источнике нет, в нем присутствует много содержательной правки и дополнений.”

T. В. Костина: "Во время совместной работы (Лавринович, Костина и О.А. Кирикова) с обеими редакциями, в одной из них была отмечена относительно последовательная замена галлицизмов на слова с германскими корнями. Это не совсем лингвистический, но переводческий момент, который тоже может быть интересен лингвистам."

С. Менгель: "Почерки этого времени очень похожи, но, может быть, в них присутствуют диалектные различия.”

T. В. Костина: "Во время поиска в СПбФ АРАН немецкоязычных документов, написанных почерком этого же писца, было установлено, что очень похожими почерками обладали И.Г.Гмелин-младший и гравер Академии наук Г. Унферцагт. Оба они родились в 170о-е гг. и могли учиться по одним и тем же пособиям, причем Гмелин происходил из юго-западной части Германии.”

После небольшого перерыва по приглашению ведущей секции Т. В. Костиной короткое пояснение перед возобновлением работы секции сделал В. С. Ржеуцкий: “Последние четыре доклада секции подготовлены в рамках трехлетнего франкороссийского проекта об истории изучения языков в России XVIII в. Этот проект поддержан Российским фондом фундаментальных исследований с российской стороны и Домом наук о человеке с французской стороны. ${ }^{20}$ Его цель -- показать главные тенденции в изучении наиболее важных для истории России XVIII в. языков. Это, прежде всего, латынь, немецкий, французский, итальянский, а также русский языки. Мы будем прослеживать процессы изучения языков в основных социальных группах, которые обращались к иностранным языкам в то время, т.е. среди дворянства и духовенства, прежде всего, и на примере главных учебных заведений для этих социальных групп: это Гимназия Академии наук, Сухопутный шляхетный кадетский корпус и семинарии."

$$
* * *
$$

Доклад “Социальный состав учеников и иностранные языки в школах и пансионах Петербурга в 1780 г.” сделала Т. В. Костина. Одна из задач проекта, о

${ }^{20}$ Доклады Т. В. Костиной, Е. И. Кисловой, В. С. Ржеуцкого, Р. Бодена и В. Береловича подготовлены при финансовой поддержке РФФИ и ФДНЧ, в рамках научного проекта № 20-51322001. 
котором рассказал В. С. Ржеуцкий, -- выявить факторы, влиявшие на выбор языка обучения в России XVIII в., понять, насколько он был детерминирован социальным происхождением. Пансионы второй половины XVIII в. представляют в этом отношении особый интерес, потому что выбор языков преподавания в них был обусловлен не столько возможностями преподавателей, сколько рыночными механизмами спроса на тот или иной язык.

Источник, на анализе которого построен доклад, извлечен из двух архивов, РГАДА и СПбФ АРАН, и имеет название “Описание находящихся в Санктпетербурге 26 школ и пансионов немцами или французами содержимых, так как оне при учиненном по всемилостивейшему Ея Императорскаго Величества именному повелению присланному к г. Директору Академии наук екзаммене назначенными к тому Академиками в марте и апреле месяцах 1780 года оказались,” с продолжением “О школах Российских." 11 Осмотр школ и пансионов с последующим подробнейшим отчетом был заказан Екатериной II перед встречей с Иосифом II, состоявшейся 18 мая 1780 г. Список учебных заведений, надлежащих к осмотру, был сформирован из списков пансионов и учеников, представленных полицейской управой, которая имела представление о школах в своих районах. Можно полагать, что в него вошли все действующие школы, за исключением домашних, создаваемых под обучение отдельных учеников конкретных фамилий и их окружения, как правило, дворян.

В пансионы отдавали детей достаточно обеспеченные представители разных социальных слоев, от специалистов из мещан (хлебник, парикмахер, лакей и др.) до генералов на военной службе. Для целей анализа пансионы были разделены на три категории по социальному составу учеников. К пансионам I типа отнесены те, в которых более 70\% родителей учеников были потомственными и личными дворянами. В пансионах II типа родителей-дворян было от 13 до 34\%, но случаи с низким процентом дворян компенсировались более высоким социальным статусом отдельных учеников (в пансион А. В. Гартвига, где дворян было 13\%, отдавали детей и чиновники VII класса). В пансионах третьего типа родителей дворян было от о до 16\%, но в пансионе Л. Шумахера, где их было 16\%, отец с самым высоким чином был штык-юнкером.

Внутри каждой группы имелись разные предложения: от программы, приближающей пансионы к академическим гимназиям, до поверхностного обучения азам. Заметно, что практически все стремились к преподаванию/изучению французского и немецкого языков, но в пансионах III типа редко могли это обеспечить, ограничивались обучением чтению и письму на русском языке. Латынь преподавали в четырех пансионах, итальянский в одном. Это пансионы, где преобладали дети купцов, представители свободных профессий, специалисты высокого уровня; в пансионах I типа латынь не преподавали. Немецкий язык был несколько более распространен в обучении в этих пансионах, что было обусловлено, по-видимому, большим числом немецкоговорящих учеников, для которых он был родным. Можно полагать, что в значительной части пансионов мы имеем дело с билингвальным составом

\footnotetext{
${ }^{21}$ РГАДА, ф. 17, оп. 1, д. 3: Переписка Кабинета е.и.в. по Академии наук, 1724-1794 гг. Ч. 4 (2), 58-95 (RGADA, f. 17, op. 1, d. 3: Perepiska Kabineta e.i.v. po Akademii nauk, 1724-1794 gg. Ch. 4 (2), 58-95); СПбФ АРАН, ф. 1, оп. 2-1780, д. 4 Протокольные бумаги. Май, 2-52 об. (SPbF ARAN, f. 1, op. 2-1780, d. 4 Protokol'nye bumagi. Mai, 2-52 ob.).
} 
учеников (русско-немецким), для которых изучаемые языки (русский и немецкий) являлись один родным, а второй иностранным. Исключение составляют пансионы первого типа, в некоторых из них иностранцев не было совсем.

Способы преподавания языков были самыми разными и зависели как от уровня пансиона, так и от личности его устроителя. Лишь в некоторых пансионах III типа основными методами становились списывание и заучивание катехизиса наизусть. В некоторых продвинутых пансионах практиковалось наглядное обучение. Были распространены переводы и устные беседы с учениками на изучаемых языках.

\section{Вопросы и дискуссия:}

В. С. Ржеуцкий: “Можно ли на основе 'Описания' сделать подсчет детей иностранцев в пансионах? Есть мнение, что пансионы в Москве и Петербурге в Екатерининскую эпоху обслуживали прежде всего потребности иностранных землячеств в этих городах; что количество учеников из иностранцев было более $50 \%$.

T. В. Костина: “По всем пансионам иностранцев было значительно меньше половины, но они, конечно, присутствовали. Вопрос об их численности важен как для изучения национального состава, так и для изучения учебного процесса. Из 'Описания' мы можем видеть, в основном, фамилии учеников, из которых большая часть, скорее всего, родилась в Петербурге. Однако есть несколько пансионов, где учились, в основном, иностранцы. Можно предполагать, что русских учеников отдавали в них намеренно, для лучшего усвоения иностранных языков, на которых дети общались и во внеучебное время."

Н. А. Хриссидис (Университет Южного Коннектикута, Нью-Хейвен): “В вашей презентации упоминаются прочие языки. О каких языках идет речь?”

T. В. Костина: “Описание’ не позволяет понять, что это за прочие языки, о которых упоминали владельцы некоторых пансионов в рекламных целях.”

С. Менгель: "Как изучался русский язык? Использовались ли для этого грамматики?”

T. В. Костина: “Дело с преподаванием языков грамматическим способом в Петербурге обстояло не очень хорошо. Массовый срез по этому поводу был получен за 1757 г., в связи с введением обязательных экзаменов для гувернеров в Академии наук и Московском университете. Очень малый процент учителей оказался способен к преподаванию грамматики языка. К 1780 г. ситуация незначительно изменилась в лучшую сторону. И хотя в пансионах I и II типа использовали грамматики, изданные при Академии наук, у экзаменаторов были нарекания к учителям. Во многих пансионах III типа учителя правили тексты детей 'по своему разумению,' используя собственные прописи; дети в них делали ошибки, характерные для тех, кто учится правописанию 'из практики,' а не по правилам грамматики." 
В докладе "Иностранные языки в семинариях XVIII века и методы их распространения” Е. И. Кислова (Московский государственный университет им. М. В. Ломоносова) поставила вопрос: как достаточно специфические социальные условия семинарского образования влияли на преподавание языков в них? Основное отличие семинарского образования от дворянского -- это его массовость. По указам Петра I все дети духовного сословия обязаны были получить образование в “школах," чтобы остаться внутри сословия и получить духовный чин. Соответственно, в течение XVIII в. росло как количество семинарий, так и число детей в них. Образование все равно не было всеобщим, но в центральных губерниях оно стало к концу века достаточно массовым. Из-за этого в классах семинарий часто оказывалось чрезмерное количество учеников (особенно в начальных классах). ${ }^{22}$ При этом каждый ученик мог проходить один класс несколько раз подряд (либо из-за неспособности к наукам, либо наоборот - для того, чтобы к старшим классам, которые давали право на выход в духовный чин, не подошел слишком юный по возрасту ученик). Всё это формировало существенные отличия методов и способов семинарского преподавания от светского.

Второй особенностью семинарий была традиционная ориентация на латынь, которая постепенно превращалась из изучаемого предмета в язык преподавания. Содержание преподавания было ориентировано на польско-украинскую иезуитскую модель (реализованную в Киевской академии). И эта традиционность порождает проблемы для исследователей, потому что, в отличие от состава учителей, содержание преподавания крайне редко фиксировалось в документах. Ежемесячные

“репорты” учителей появляются только с 1785 г. До этого момента в реконструкции методов преподавания и содержания курсов нам приходится опираться на косвенные данные и отдельные сохранившиеся учебные материалы.

Основным методом обучения латыни в семинариях было заучивание больших фрагментов текста и списков слов. Грамматический метод начинает появляться в преподавании латыни в последней четверти XVIII в., однако изучение грамматики также превращалось в заучивание наизусть образцовых русско-латинских грамматик (главным образом -- грамматики В.И. Лебедева). ${ }^{23}$ Отчеты показывают, что один и тот же раздел грамматики могли параллельно слушать ученики разных классов, но при этом старшим давали более сложные задания и привлекали больше дополнительный материал. При этом ученики могли поступать в классы на протяжении всего года, поэтому изучение грамматики “по

\footnotetext{
${ }^{22}$ См. подробнее: Е. I. Kislova, "Latin' and 'Slavonic' Education in the Primary Classes of Russian Seminaries in the 18th Century," Slověne = Словъне. International Journal of Slavic Studies 4: 2 (2015), 7291.

${ }^{23} \mathrm{O}$ составе грамматик и методах работы с ними в семинариях см.: Е. И. Кислова, "Учебные пособия по латыни и их использование в семинариях XVIII в.," Ученые записки Новгородского государственного университета 5:30 (2020): 9. (E. I. Kislova "Uchebnye posobiia po latyni i ikh ispol'zovanie v seminariiakh XVIII v.," Uchenye zapiski Novgorodskogo gosudarstvennogo universiteta 5:30 (2020): 9).
} 
кругу” оказывалось оправдано: каждый ученик рано или поздно мог выучить все ее разделы, пусть и не с начала.

Когда в последней трети XVIII в. в семинариях было введено преподавание новых европейских языков, оно попало в ту же модель, что и преподавание латыни. Происходило это в том числе потому, что учителя-иностранцы в семинариях использовались только на самом начальном этапе “заведения" классов, и уже через пару лет их сменяли студенты и выпускники семинарий, их труд был намного дешевле. ${ }^{24}$ Большое количество учеников в классах и нехватка учителей приводили к ориентации обучения на заучивание и письменный перевод, что естественным образом создавало проблемы с устной речью на иностранных языках.

\section{Вопросы и дискуссия:}

В. С. Ржеуцкий: "Можно ли из сохранившихся документов составить представление о том, когда появился грамматический (морфологический и синтаксический) анализ в преподавании латинского языка?"

Е. И. Кислова: "Во второй половине XVIII в. закупались грамматики, и с грамматикой ученики имели дело. Но до 1802 г. у нас нет никаких сведений о том, как выглядел грамматический анализ. В отчетах регулярно употребляется штамп о разборе заданий по 'форме грамматико-этимологической резолюции,' но что под ним подразумевалось, пока достоверно установить не удается.”

А. И. Вачева (Софийский университет): “Известно, что в Западной Европе учили латинский язык, читая Энеиды Вергилия. Использовался ли этот текст в качестве дополнительного чтения в русских семинариях XVIII в.?”

Е. И. Кислова: “Использовали очень много текстов. В первую очередь это был Цицерон, Юлий Цезарь, для начальных этапов басни Федра. Вергилий использовался, но не в каждой семинарии, а, видимо, в случаях, когда в библиотеке была сама книга."

Н. Хриссидис: “Какого вероисповедания были учителя иноверцы?”

Е. И. Кислова: “В основном это были немцы-лютеране, они преподавали даже французский язык. При этом у семинарий центральной части России были хорошие связи с Германией, в первую очередь с Галле. А у украинских семинарий более тесные связи были с католическими странами -- Польшей, Венгрией и т.д."

\footnotetext{
${ }^{24} \mathrm{O}$ составе преподавателей французского и немецкого языков в семинариях см.: Е. И. Кислова, “Из истории лингвистической компетенции духовенства XVIII в.: учителя европейских языков в русских семинариях," Вестник Московского университета. Серия 9. Филология 2 (2016): 61-76. (Е. I. Kislova, "Iz istorii lingvisticheskoi kompetentsii dukhovenstva XVIII v.: uchitelia evropeiskikh iazykov v russkikh seminariiakh,” Vestnik Moskovskogo universiteta. Seriia 9. Filologiia 2 (2016): 61-76).
} 
М. К. Брагоне (Университет г. Павия): "У меня небольшие замечания о грамматическом анализе. Разбор разных частей речи находится уже в букварях конца XVII -- начала XVIII в. и в грамматике М. Смотрицкого.”

Е. И. Кислова: “Конечно, даже до грамматики В. И. Лебедева в обучении использовали 'альвары' и через них семинаристы получали представления о частях речи, о спряжениях. Эти грамматики они выучивали наизусть. Но как это прикладывалось к конкретным лингвистическим задачам в процессе обучения -до конца века остается большим вопросом."

А. А. Голубинский (Институт российской истории Российской Академии наук): “С кого начинали при формировании запроса на подготовленные кадры для работы на государственной службе, с самых подготовленных или с отстающих?"

Е. И. Кислова: “Действительно, из семинарий забирали часть хорошо подготовленных в латинском языке учеников в госпитали, в Гимназию при Академии наук и т.д. Руководство семинарий, разумеется, не хотело отдавать самых сильных студентов, даже если те рвались на эту службу. Например, сохранилась переписка церковных иерархов, в которой откровенно обсуждается, что их необходимо сохранить в церкви для преподавания в тех же семинариях. А слабых учеников могли отправлять без проблем, правда, например, Академия наук после экзаменов их могла вернуть назад как неспособных и недостаточно владеющих латынью.”

Р. Боден: “Живая речь в преподавании новых языков страдала, и Вы объясняете это тем, что среди преподавателей было мало носителей, может быть это объясняется массовым характером преподавания?"

Е. И. Кислова: “Может, конечно. Даже в лучших семинариях типа Троицкой, где Платон Левшин обязывал семинаристов общаться между собой на французском и немецком языках, массово обеспечить хорошую подготовку было невозможно."

М. Шруба: “В каком возрасте начинали учебу в семинариях?"

Е. И. Кислова: “В начальные классы могли поступать (очень редко, например, сироты) с семи лет. Чаще до восьми-десяти лет дети оставались дома и должны были под руководством отца освоить чтение и письмо на русском и церковнославянских языках. А дальше они могли учиться до 20 с лишним лет или выходить из семинарии раньше, уже после класса риторики. В духовное звание могли выходить примерно с 18 лет, но какие-то должности (дьячка, пономаря) по особому разрешению могли занять и раньше."

$$
* * *
$$

В. С. Ржеуцкий в докладе "Использовались ли упражнения в изучении языков в России XVIII века?” сосредоточил внимание преимущественно на изучении 
французского как иностранного языка русскими дворянами. ${ }^{25}$ Слово упражнение (фр. exercice) встречается в учебниках для изучения иностранных языков XVIII в. весьма редко. В одном из самых популярных учебников, написанном Ж. Р. Пеплие, это слово использовано, причем в двух значениях. Во-первых, упоминается об упражнениях в языке. Во-вторых, в указателях под ехегсісе понимается перевод с родного языка на изучаемый. П. Ресто, автор другого популярного учебника, понимал под упражнением усердную практику в языке и утверждал, что "знание [языка] приобретается только длительным упражнением и не может быть механическим.”26 Если мы посмотрим на другие учебники, которые использовались в России в XVIII в. и даже в первой половине XIX в., то в них нет того, что мы сейчас подразумеваем под упражнениями. Но значит ли это, что для XVIII в. мы ни о каких упражнениях не можем говорить?

Какими способами вообще учили языки? 1. В архивах русских аристократов (кн. Барятинских, в. кн. Александра Павловича) найдены диктанты. 2. Использовали грамматики, но их структура не содержала упражнений. Например, в грамматику Пеплие кроме части, посвященной объяснению правил грамматики, с большим числом переведенных на немецкий язык примеров, включены тематические списки слов с переводом на немецкий, диалоги на французском с параллельным переводом на немецкий, тексты для чтения и примеры писем с объяснениями о видах писем и правилах их написания. Грамматики, публиковавшиеся в России, например, Г. А. Теплова (1762), следуют аналогичной модели. Учебники начала XIX в. продолжали традицию, однако в них появляются примеры грамматического анализа. 3. Употребляли сборники диалогов. Например, в Гимназии Академии наук и Кадетском корпусе использовали Colloquia scholastica (1738). 4. Использовали также резюме-пересказ. На примере фрагмента резюме, написанного Александром Павловичем и исправленного Ф. С. Лагарпом видно, что при их использовании преследовалось одновременно две цели: изучение истории и языка. Это вряд ли удовлетворяет современным представлениям об упражнениях с их фокусом на механическое повторение. Перевод ближе к упражнениям, но он вряд ли преследовал цели повторения и отработки какого-то конкретного грамматического правила или структуры. 5. Наконец, важный способ изучения языка в дворянской среде -- это письмо, которое было и основным способом учтивого общения. Дети нередко (например, в семье княгини Н. П. Голицыной) писали письма начерно, затем их правили гувернеры, после чего письмо переписывалось набело и отправлялось родителям. В процессе усваивались определенные языковые формулы вежливого обращения. Повторяемость этих формул сближает письмо с упражнениями, но мы не знаем, велась ли в процессе работа над какими-то выражениями в отдельности.

Отдельные высказывания, которые мы встречаем в XVIII в. в описаниях обучения языкам, наводят на мысль о том, что какие-то упражнения все-таки были уже тогда. Упоминаются занятия в склонениях и спряжениях, “в делании из

\footnotetext{
${ }^{25}$ Об этом см. также: Vladislav Rjéoutski, “Utilisait-on des 'exercices' pour l'étude du français en Russie au XVIIIe siècle?" Documents pour l'histoire du français langue étrangère ou seconde, 62-63 (2019): 167185, http://journals.openedition.org/dhfles/6771.

${ }^{26} \mathrm{P}$. Restaut, Principes généraux et raisonnés de la grammaire françoise, avec des observations sur l'orthographe, les accens, la ponctuation et la prononciation (Brussels: chez Jean Leonard, 1740), IV.
} 
единственного числа множественного, из мужского рода женский” (например, в

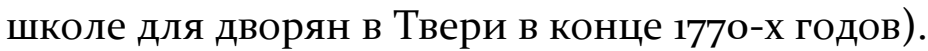

Итак, ряд действий в обучении языку имели отдельные характеристики упражнений. Например, повторяющееся употребление формул при написании писем. Однако были ли эти действия направлены на отработку определенных правил, и были ли формулы разбиты на минимальные единицы, и можем ли мы сказать, что целью было достижение автоматизма? На эти вопросы однозначно ответить нельзя. Изучению языков в XVIII в. был чужд механический подход, в эту эпоху скорее придерживались глобального подхода, которому была несвойственна аналитичность, которую мы увидим в XIXв. Главной основой были тексты. Аналогично дело обстояло и с изучением языков в Европе. Можно сказать, что использование упражнений было несовместимо с духом XVIII в., который отвергал фрагментацию и механическую сторону будущих упражнений.

\section{Вопросы и дискуссия:}

В. Берелович: “Я полностью согласен с твоим анализом. Меня заинтересовало само слово exercice. Возможно, конец XVIII в. это переходный период, когда слово exercice стало употребляться во множественном числе, тогда как в начале века оно означало практику. Его употребляли, говоря о враче, плотнике... В значении 'педагогические упражнения' это слово начали употреблять позже.”

В. С. Ржеуцкий: “Да, вполне возможно. Грамматический анализ, например, появляется довольно поздно, возможно в конце XVIII в., и в начале XIX в. мы его уже видим. Я думаю, это тоже связано с традицией изучения языков, когда упор делался на цельность, полифункциональность текстов, когда они использовались одновременно для изучения грамматики и синтаксиса, географии и истории. Это характерно для XVIII в., в более поздние периоды мы этого не находим.”

P. А. Евстифеева: “Спасибо за очень интересный доклад. Вы сравниваете методы изучения языков в XVIII в. с некоторым образцом, в котором присутствуют упражнения, расчленение текста на маленькие фрагменты. Встраивать методику преподавания языков в XVIII в. в некоторую типологию правильно, но на самом деле и сегодня эти способы не так экзотичны и уникальны. Ближе всего это к тому, что называется 'content and language integrated learning.' Но, конечно, у него есть и серьезные отличия. На мой взгляд, типологию сравнений можно расширить."

В. С. Ржеуцкий: “Когда я говорил о современных упражнениях, то, скорее, ориентировался на XX в., потому что учился сам в то время. Я также использовал известную и хорошо описанную разбивку видов упражнений, которая сформировалась в XX в. во Франции. Сейчас, вероятно, ситуация меняется, и сравнить ее с упражнениями в XVIII в. -- это уже совсем другая задача.”

P. Боден: “Из приведенных сборников диалогов видно, что перевод этих диалогов не был прямым и буквальным. В нем заменены штампы из русского языка на 
штампы из французского языка. Т.е. это было скорее обучение светским компетенциям, чем преподавание языка."

В. С. Ржеуцкий: "Мне кажется, и то, и другое. Трудно разделить эти компетенции из-за стремления к особому глобальному подходу в обучении. В семье Барятинских изучали одновременно четыре языка и переводы делали без участия русского, например, с немецкого на французский, а тексты были не только наполнены формулами светского общения, но и подобраны не случайно, а с мыслью, например, об их моральном содержании.”

М. Б. Лавринович: “Отвлекаясь от языка как системы знаков и переходя к языку как телесной практике хочу заметить, что глагол drillen, обозначающий муштру, зубрежку, -- это глагол XVIII в. Употреблялся ли он в то время применительно к изучению языков?"

В. С. Ржеуцкий: “Формы обучения языкам были разные в зависимости от среды, социального окружения и учебного заведения, о котором мы говорим. Например, мне встречалась критика пансионного образования за то, что оно было основано на механическом повторении, и в этом плане оно отличалось от того, как учили в дворянских семьях."

Совместный доклад “Обучение русских студентов-аристократов иностранным языкам в рамках Гран-тура: пример Голицыных в Страсбурге” представили Р. Боден и В. Берелович. На основе изучения предисловий к разным учебникам по иностранным языкам, опубликованным во Франции XVIII века, авторы доклада попытались реконструировать список аргументов в пользу обучения тому или иному языку молодым дворянам, в том числе дворянам из России, учившимся в Страсбурге.

Историк Юрген Фосс (Jürgen Vos) подсчитал количество студентов из Российской империи, записавшихся в Страсбургский университет с 1754 г. по начало Французской революции (138 человек). Личные отношения между сотрудниками Страсбургского университета и Петербургской академии наук способствовали установлению привилегированных условий для русских студентов в Страсбурге, в том числе выделению стипендий для небогатых студентов. Второй причиной популярности этого города среди русских дворян была возможность получить образование немецкого уровня в стране, не находящейся под угрозой Семилетней войны. Большую часть студентов из Российской империи в Страсбурге составляли молодые дворяне из семей знати или представители прибалтийского дворянства. Эти студенты изучали не медицину и не естественные науки, как их бедные товарищи; их социальное происхождение предназначало их к престижным карьерам в дипломатии или в армии. Многие из них поступали в так называемую Дипломатическую школу, основанную Иоганном Даниэлем Шёпфлиным в 1752 г. После смерти Шёпфлина в 1777 г. главой школы стал его ученик, юрист и историк Кристоф Гийом Кох, у которого с 1760-х г. были связи с Голицыными, возникшие благодаря 
посредничеству братьев Фредерика Альбера Коха и Конрада Рене, служивших при Дмитрии Михайловиче Голицыне в Вене. Из Голицыных в Страсбурге учился Николай Алексеевич (его гувернером стал Конрад Рене Кох), Дмитрий Михайлович (с гувернером эльзасцем Бринкманом), Михаил Петрович (с гувернером эльзасцем Хекелем), а также сироты Михаил, Борис и Алексей Андреевичи (с гувернером Я. Сокологорским, которого сменил эльзасец Блессиг).

Выбор языков в учебных планах Голицыных был обусловлен не только социальной значимостью этих языков, но и тем, какие лингвистические компетенции казались важными для молодых дворян, метивших на дипломатическую или военную службу. Призывы преподавать иностранные языки умножились, начиная с 1760-х гг., и сочетание немецкого, английского и итальянского языка быстро стало общепринятым во Франции. Важность немецкого языка для военных и дипломатов связывали в трактатах 1760-х-1780-х гг. с тем, что войны, которые вела Франция, происходили, в основном, на немецких территориях. Некоторые авторы подчеркивали и важность немецкого языка как ученого, в особенности, для медицины, естественной истории и металлургии. Необходимость изучения итальянского языка в случае с Голицыными обосновывалась его значением для получения удовольствия и пользы от Гран-тура по Италии. Английский язык признавался важным для развития точных наук и нужд торговли. Голицыных он привлекал как дипломатический язык и язык просвещенной страны, институты которой восхищали многих русских аристократов.

Практика изучения иностранных языков Голицыными восстанавливается на основе переписки юных представителей этого рода (и их гувернеров) с их дядями, опекунами и кураторами. Парадокс в изучении языков заключался в том, что им, с одной стороны, выделяли очень скромное место в обсуждениях, значительно чаще речь заходила об общеобразовательных предметах. Из всех корреспондентов только А. М. Голицын беспокоился об усвоении языков, да и то гораздо больше о владении русским, чем другими языками. С другой стороны их, как и математику, считали фундаментом, без которого нельзя двигаться дальше.

О французском языке в переписке упоминали редко, молодые Голицыны владели им на очень высоком уровне, на нем преподавали все общеобразовательные предметы. Как предмет преподавания он, если и появляется в учебных планах, то на уровне стиля и/или при изучении французской литературы. Исключением был Алексей Андреевич, которому французский язык преподавали и после учебы в Страсбурге. Немецкий язык изучали все Голицыны, внимание ему уделялось наравне с французским языком, но уровень владения был ниже. Итальянский и английский выступали на втором плане, степень их усвоения зависела от языкового уровня воспитанников. Они были нужны, в основном, для успешного совершения Гран-тура. Латынь не упоминалась в учебных планах и представляла собой особую область. Отношение к латыни в России и во Франции в XVIII в. было диаметрально противоположным. Если Россия только открывала для себя значение латыни в культуре, то во Франции она медленно теряла свою важную роль, а латинская литература активно заменялась переводами латинских авторов на французский. Н. А. Голицын занимался латынью во время учебы в Стокгольме и “потихоньку" совершенствовался в ней с 1769 г. О Д. М. Голицыне заранее было объявлено, что 
специально заниматься латынью у него нет времени, но он должен иметь какоето понятие о ней, чтобы уметь поддержать разговор во французских салонах и “как следует" посетить Италию, судить о красоте ее памятников.

Об учителях иностранных языков известно немногое. По-видимому, они были носителями преподаваемых языков, и среди них был, по меньшей мере, один профессор и один “мастер.” По сравнению с профессорами университета, которые преподавали Голицыным право и историю, их заработки были в 3-4 раза меньше. Учитель фехтования получал в 2-3 раза больше учителей языков.

В учебных планах нет упоминаний учебников. Все данные свидетельствуют о том, что часто употреблялся перевод с немецкого на французский и обратно. Возможно, у дворян были проблемы с владением русским языком. Например, трех братьев Андреевичей заставляли читать Евангелие для того, чтобы поддерживать их в вере, улучшить понимание русского и церковнославянского языков. Евангелие они должны были сверять с французским языком, что говорит, вероятно, о том, что церковнославянский язык они знали хуже, чем французский. До начала 1780-х годов дети писали письма исключительно на французском, но затем Александр Михайлович Голицын настоял на том, чтобы ему писали порусски.

Выводы: в целом, анализ сведений о практике языка подтверждает ориентацию на изучение новых языков, что еще ярче выражено в случае с Голицыными, чем в дворянских учебных заведениях России. Система воспитания Голицыных представляет слияние потребностей русской аристократии и того, что предлагала Дипломатическая школа в Страсбурге. Вероятно, пример Голицыных является достаточно репрезентативным для российской аристократии, но чрезмерно его обобщать не стоит.

\section{Вопросы и дискуссия:}

P. А. Евстифеева: “Мой вопрос, на самом деле, адресован всем, кто сегодня делал доклады про педагогические системы. Есть ли у нас какие-то свидетельства того, что думали сами учащиеся о способах обучения?”

В. Берелович: "В случае с Голицыными нет. Их критика направлена на гувернеров, на Коха, но не на систему преподавания.”

P. Боден: “Когда один из Голицыных очень не хотел учить немецкий, у гувернеров была установка доказать этому молодому человеку, что ему имеет смысл учить этот язык, пробуждая его вкус к новой немецкой литературе."

Дж. Ларокка: “Известны ли учебники, по которым Голицыны учили итальянский язык?"

В. Берелович: "Упоминаний нет. Только один раз упоминается франкоитальянский лексикон, купленный перед поездкой в Италию.”

P. Боден: “Мы можем предполагать, какие учебники использовались, реконструируя круг популярных учебников в среде дворян того времени. 
Например, для преподавания немецкого языка, вероятнее всего, использовали грамматику Готшеда просто потому, что она была суперпопулярна в то время. Но наши поиски учебной литературы затрудняет то, что Голицыным преподавали профессора, которые были прекрасно осведомлены о достижениях немецкой науки, но готовили учеников для французской дипломатической службы на французском языке.”

В. С. Ржеуцкий: “Изучая круг лиц уровня Голицыных, -- это другая ветвь Голицыных, Строгановых, Барятинских я тоже не нашел ни одного примера использования учебников. Возможно, это характерно для этой среды."

В. Берелович: “Известно, что молодые аристократы учились в России по нескольким учебникам, в т.ч. используя Телемака. Но можно ли его считать учебником? В письмах учеников-аристократов проскальзывают цитаты, но они не из учебников, а из каких-то книг."

В. С. Ржеуцкий: "Р. Боден говорил о полезности языков на основе французской и другой европейской литературы, есть ли в документах Голицыных какие-то упоминания об этих трактатах?"

Р. Боден: “Насколько я себе представляю, нет. Но мы исходили из посылки, что нельзя разделять теоретические идеи, с одной стороны, и практику в семье Голицыных, с другой, хотя бы потому, что планы их обучения составлялись коллективно в дискуссиях, при непосредственном участии Коха." ${ }^{7}$

В. С. Ржеуцкий: "Встречается ли в документах какая-то аргументация в пользу того, чтобы учить русский язык? В 1780-е гг. об этом много говорят в России.”

В. Берелович: “Да, это правда. Уже с конца 1770-х обращают особое внимание на владение Голицыными русским языком. Причины указываются моральные, что русскому необходимо уметь говорить на родном языке, а также указываются соображения государственной службы."

Р. Боден: “Есть предположение, что Голицыны брали уроки русского языка у тех небогатых студентов в Страсбурге, которые приезжали учиться медицине и естественным наукам."

Г. Байер-Тома (Институт Восточной Европы в Регенсбурге): “Возможно, переход связан с общеевропейским движением национализма. Я помню, что Я. Штелин много лет вел переписку с немецким дипломатом на французском языке, но в 1770-е гг. они перешли на немецкий язык, не понимая, почему они должны использовать французский."

\footnotetext{
${ }^{27}$ Подробнее см.: C.-G. Koch, Histoire de Russie, avec sa partie politique, suivie de la Constitution de l'empire de Russie, par Mr. Koch, professeur à Strasbourg, eds. R. Baudin \& W. Berelowitch (Strasbourg: Presses universitaires de Strasbourg, 2018).
} 
С. М. Шамин: “Чтение религиозных текстов -- это не обязательно изучение русского языка, скорее речь идет о практике именно церковнославянского текста."

В. С. Ржеуцкий: “Русский и церковнославянский рассматривались как языки напрямую взаимосвязанные. Это видно по тому, что пишет Бецкой при основании Кадетского корпуса, что нужно упражняться в церковнославянском, потому что это важно и для русского языка."

Е. И. Кислова: “Нужно еще смотреть, какие конкретно религиозные тексты они читали. Потому что если это был, например, Катехизис Платона, то в нем грамматическая русская основа, а в Псалтыри церковнославянская.”

С. М. Шамин: “Я только хотел заметить, что речь могла идти не о знании русского языка, а о повышении культуры речи.”

T. В. Костина: “Да, это очевидно, потому что мы видим на примере переписки того времени, что церковнославянские фразы считались маркером хорошей речи именно в слоях образованных русских того времени."

$$
* * *
$$

Многие в этом непростом году уже отметили неожиданные преимущества дистанционного общения, позволяющие с легкостью привлечь к обсуждению той или иной проблемы специалистов из разных городов. В случае с секцией “Миллеровских чтений," посвященной функционированию и изучению иностранных языков в России XVIII в., это преимущество было несомненным. Оно позволило прослушать доклады, сделанные на русском языке, 49 специалистам из разных стран: Болгарии, Великобритании, Германии, Италии, России, США, Франции, Швеции. Вопросы и дискуссии после докладов продемонстрировали их высокую заинтересованность представленными в докладах материалами и выводами.

Заседание носило междисциплинарный характер. В нем приняли участие и филологи, и историки. А проблематика докладов позволила с разных сторон, взглянуть на проблему функционирования иностранных языков в Век Просвещения: проанализировать разницу в запросах на иностранные языки у разных социальных групп, существовавшие ограничения в преподавании иностранных языков, переводческой деятельности, затронуть особенности их ситуативного применения на примерах подносных экземпляров Петру I и Екатерине I, “Проекта об учреждении Академии наук” и использования разных языков полиглотом Я. Штелиным, затронуть проблему публикации билингвальных и мультилингвальных источников. 